九州大学学術情報リポジトリ

Kyushu University Institutional Repository

\title{
General Chemical Fertility and Chemical Processes of Grey Degraded Soils as a Problem Soil in Viet Nam
}

Egashira, Kazuhiko

Kaieda, Akihito

School of Agriculture, Kyushu University

Do, Nguyen Hai

Department of Soil Science and Agrochamistry, Faculty of Land and Water Resources Management, $\mathrm{Ha}$ Noi Agricultural University

https://doi.org/10.5109/4514

出版情報: 九州大学大学院農学研究院紀要. 47 (2), pp.437-445, 2003-02-01. Faculty of Agriculture, Kyushu University

バージョン :

権利関係 : 


\title{
General Chemical Fertility and Chemical Processes of Grey Degraded Soils as a Problem Soil in Viet Nam
}

\author{
Kazuhiko EGASHIRA ${ }^{\dagger}$, Akihiro KAIEDA* and DO Nguyen Hai** \\ Laboratory of Soil Science, Division of Soil Science and Plant Production, \\ Department of Plant Resources, Faculty of Agriculture, \\ Kyushu University, Fukuoka 812-8581, Japan \\ (Received October 30, 2002 and accepted November 7, 2002)
}

\begin{abstract}
General chemical properties were analyzed for profile samples of four grey degraded soils collected at the sites different in land use, landform, and parent material, in Viet Nam. The chemical fertility of grey degraded soils was found to be commonly poor in organic matter, the nitrogen and phosphorus status, and exchangeable "bases". The vertical movement of free iron oxides was observed for the paddy soils and the simultaneous movement of organic components and free iron oxides was suggested for the forest soil. Reduction and oxidation was considered to the paddy soil while podzolization was to the forest soil as mechanisms of the eluviation-illuviation of the chemical compounds. The mechanism of the clay degradation was reevaluated: decomposition of clay particles in addition to leaching and accumulation was suggested to the paddy soil, while leaching and accumulation was proposed as a main mechanism to the forest soil. The careful management such as regular addition of organic amendments and split dressing of chemical fertilizers, in addition to application of iron-supplying material, was recommended to the cultivation of paddy rice in the degraded paddy field.
\end{abstract}

\section{INTRODUCTION}

Viet Nam is located in the eastern part of the Indochina peninsula and is S-shaped with the long north-to-south distance of about $1,650 \mathrm{~km}$. The total land area of the country is $331,100 \mathrm{~km}^{2} ; 28 \%$ of the land is plain and the remaining $72 \%$ is mountain or hill. Viet Nam belongs to tropical to subtropical monsoon with two distinct rainy (April to October) and dry (November to March) seasons.

In Viet Nam with a long history of agricultural production, there are several types of problem soils having different limiting factors to crop production. At present five types are classified as such: sandy marine soils, saline soils, acid sulfate soils, grey degraded soils, and eroded skeletal soils. Among them, grey degraded soils are distributed in the border between plains and mountains or hills. They are derived from old alluvium, sandstone or acid igneous rocks. The formation of grey degraded soils has been attributed to the intensive weathering and leaching processes under tropical to subtropical monsoon climate. As a result, the following characteristics are commonly identified: the light grey color in the surface horizon(s) with coarse texture; eluviation in the A2 or AB horizon (similar to the albic horizon) due to leaching of fine particles and iron oxides; and accu-

\footnotetext{
* School of Agriculture, Kyushu University, Fukuoka 812-8581, Japan

** Department of Soil Science and Agrochemistry, Faculty of Land and Water Resources Management, Ha Noi Agricultural University, Gia Lam, Ha Noi, Viet Nam

† Corresponding author (E-mail: kegashi@agr.kyushu-u.ac.jp)
} 
mulation of plinthite or laterite layers in the subsurface horizons. Grey degraded soils are classified as Acrisols according to the FAO/UNESCO soil classification system.

Grey degraded soils are characterized by the poor soil fertility in the surface layers. Concerning chemical properties of them, Nguyen and Do (1977), Nguyen and Tran (1978), Dao (1987), and Thai and Nguyen (1998) have reported that they are strongly acid with the $\mathrm{pH}(\mathrm{KCl})$ of 4 to 5 , low in the organic matter content ( 8 to $12 \mathrm{~g} \mathrm{~kg}^{-1}$ ), very low in cation exchange capacity $\left(6\right.$ to $8 \mathrm{cmol}_{\mathrm{c}} \mathrm{kg}^{-1}$ ), and deficient in all plant-nutrients. Nguyen et al. (1995) found that almost all grey degraded soils had the coarse texture of sand to loamy sand in the surface horizons.

In the previous paper (Do et al., 2002), we analyzed the particle-size distribution and the clay mineral composition of four grey degraded soils, collected at different locations in Viet Nam. The results indicated clay degradation and the low inherent potentiality of the surface or upper horizons of the grey degraded soils. In the present study, general chemical properties of the grey degraded soils were analyzed to show the poor chemical fertility and the eluviation-illuviation processes of chemical compounds occurring in them.

\section{MATERIALS AND METHODS}

\section{Soil samples}

Brief description of four grey degraded soils is shown in Table 1. Concerning the agro-economic region of Viet Nam in which the whole country is divided into 8 zones, profiles 1, 2, 3, and 4 belong to Red River Delta, North East Midland and Mountainous, Central Highlands, and North East of South regions, respectively. Profile description and morphology of the soils were given in the previous paper (Do et al., 2002). Soil samples were taken in the dry season of 2000-01. They were air-dried and gently ground to pass through a 1-mm sieve in Viet Nam, and subjected to chemical analyses in Kyushu University, Japan.

Table 1. Brief description of grey degraded soils in Viet Nam

\begin{tabular}{|c|c|c|c|c|}
\hline Item & Profile 1 & Profile 2 & Profile 3 & Profile 4 \\
\hline $\begin{array}{l}\text { Location } \\
\text { (District, Province) }\end{array}$ & Soc Son, Ha Noi & Pho Yen, Thai Nguyen & Ea-H'leo, Dac Lac & Hoa Thanh, Tay Ninh \\
\hline Elevation (m) & $10-15$ & 30 & 270 & 18 \\
\hline $\begin{array}{l}\text { Land use } \\
\text { Cropping pattem }\end{array}$ & $\begin{array}{c}\text { Paddy } \\
2 \text { rice-winter crops }\end{array}$ & $\begin{array}{c}\text { Paddy } \\
2 \text { rice--winter crops }\end{array}$ & $\begin{array}{c}\text { Forest } \\
\text { Reforested }\end{array}$ & $\begin{array}{c}\text { Upland } \\
\text { Cashew plant }\end{array}$ \\
\hline Landform & $\begin{array}{l}\text { Moderately drained, } \\
\text { flat plain }\end{array}$ & $\begin{array}{l}\text { Moderately drained, } \\
\text { gently sloping terrace }\end{array}$ & $\begin{array}{l}\text { Well drained, undulating } \\
\text { hill with slope of } 5-8^{\circ}\end{array}$ & $\begin{array}{l}\text { Well drained, gently } \\
\text { sloping terrace }\end{array}$ \\
\hline Parent material & Old alluvium & Sandstone & Granite & Acid igneous rock \\
\hline $\begin{array}{l}\text { Soil classification by the } \\
\text { FAONNESCO system }\end{array}$ & Orthi-Plinthic Acrisol & Areni-Haplic Acrisol & Areni-Ferric Acrisol & Areni-Haplic Acrisol \\
\hline
\end{tabular}

\section{Chemical analyses}

Following methods were used for chemical analyses of soils (Editorial Committee for Methods of Soil Environmental Analysis, 1997). 
$p H\left(H_{2} \mathrm{O}\right): 10 \mathrm{~g}$ of the air-dry soil was mixed with $25 \mathrm{~mL}$ of deionized water and shaken for $30 \mathrm{~min}$ by a reciprocal shaker, followed by standing for $1 \mathrm{~h}$. The $\mathrm{pH}$ of the suspension was measured in the suspended condition with a glass electrode.

Total carbon: More than $5 \mathrm{~g}$ of the air-dry soil was finely ground, and 0.15 to $0.45 \mathrm{~g}$ of them was weighed. Total $\mathrm{C}$ content was measured by the dry combustion method with an apparatus of SSM-5000A (Shimadzu).

Total nitrogen: Measured by the Kjeldahl method.

Available phosphorus: Measured by the Truog method. In this method, available $\mathrm{P}$ was extracted with $0.001 \mathrm{M}$ sulfuric acid ( $\mathrm{pH} 3.0$ ) with a soil:solution ratio of 2:400. The concentration of $\mathrm{P}$ in the extracted solution was colorimetrically determined with the ascorbic acid method.

Exchangeable cations: Exchangeable $\mathrm{Ca}, \mathrm{Mg}, \mathrm{K}$, and $\mathrm{Na}$ were extracted with $1 \mathrm{M}$ ammonium acetate ( $\mathrm{pH} 7.0)$ with a soil:solution ratio of 2:30. The extraction was repeated three times with shaking and centrifugation. Extracted cations were determined by an atomic absorption spectrophotometer.

Free iron oxides: $0.5 \mathrm{~g}$ of the finely-ground air-dry soil was weighed into a centrifugal bottle. $0.5 \mathrm{~g}$ of sodium hydrosulfite and $25 \mathrm{~mL}$ of the citrate solution $\left(220 \mathrm{~g}\right.$ of $\mathrm{Na}_{3} \mathrm{C}_{6} \mathrm{H}_{5} \mathrm{O}_{7}$. $2 \mathrm{H}_{2} \mathrm{O}$ was dissolved into $1 \mathrm{~L}$ of deionized water) were added to the bottle, followed by shaking mechanically at room temperature, for extraction of free Fe oxides. After centrifugation at $5,000 \mathrm{rpm}$ for $10 \mathrm{~min}$, the supernatant was transferred to a measuring flask. The extraction procedure was repeated one or two times more for the samples keeping the red to yellow color. $20 \mathrm{~mL}$ of deionized water was added to the sample after extraction, and the suspension was shaken by hand several times. The supernatant was collected to the measuring flask after centrifugation. This washing procedure was repeated two more times. The extracted solution was diluted ten times with deionized water after filling-up of the flask and stood for two days in a loosely-capped plastic bottle to decompose reducing compounds. The concentration of $\mathrm{Fe}$ in the solution was determined by an atomic absorption spectrophotometer.

\section{RESULTS}

\section{Particle-size distribution and mineral composition}

Particle-size distribution and major minerals in the clay fraction of grey degraded soils were quoted from the previous paper (Do et al., 2002). They are reproduced in Table 2, along with horizon and depth. The low clay content, equal to or below $10 \%$, in the surface or upper horizons was commonly indicated, and domination of kaolin mineral (kaolinite or halloysite $(0.7 \mathrm{~nm})$ ) and/or quartz in the clay fraction was observed throughout the profile. It confirms the low inherent potentiality of grey degraded soils.

\section{pH}

Selected chemical properties of $\mathrm{pH}$, total $\mathrm{C}$ and $\mathrm{N}$, available $\mathrm{P}$, exchangeable cations, and free Fe oxides of grey degraded soils are shown in Table 3. The value is an average of the duplicate measurements, except for $\mathrm{pH}$ and free Fe oxides. As indicated in Table 3, the $\mathrm{pH}$ was mostly below 6.0 in respective horizons and as low as 4.5 in the lowest horizon of profiles 2 and 4 . The acidic nature of grey degraded soils was clearly noticed. In 
Table 2. Particle-size distribution and major minerals in the clay fraction of grey degraded soils*

\begin{tabular}{|c|c|c|c|c|c|c|c|c|}
\hline \multirow{2}{*}{$\begin{array}{l}\text { Profile } \\
\text { No }\end{array}$} & \multirow[t]{2}{*}{ Horizon } & \multirow{2}{*}{$\begin{array}{l}\text { Depth } \\
(\mathrm{cm})\end{array}$} & \multicolumn{4}{|c|}{ Particle-size distribution (\%) } & \multirow{2}{*}{$\begin{array}{l}\text { Soil } \\
\text { texture** } \\
\text { (IUSS) }\end{array}$} & \multirow{2}{*}{$\begin{array}{l}\text { Major minerals in } \\
\text { the clay fraction*** }\end{array}$} \\
\hline & & & $\begin{array}{c}\text { Coarse sand } \\
(200-1,000 \mu \mathrm{m})\end{array}$ & $\begin{array}{l}\text { Fine sand } \\
(20-200 \mu \mathrm{m})\end{array}$ & $\begin{array}{c}\text { Silt } \\
(2-20 \mu \mathrm{m})\end{array}$ & $\begin{array}{c}\text { Clay } \\
(<2 \mu \mathrm{m})\end{array}$ & & \\
\hline \multirow[t]{6}{*}{1} & Apl & $0-13$ & 31.7 & 36.6 & 21.6 & 10.1 & SL & $\mathrm{Kt}>\mathrm{Qr}, \mathrm{Mc}$ \\
\hline & Ap2 & $13-22$ & 25.0 & 41.2 & 24.9 & 8.9 & SL. & $\mathrm{Kt}>\mathrm{Qr}, \mathrm{Mc}$ \\
\hline & $\mathrm{AB}$ & $22-31$ & 22.8 & 43.4 & 21.9 & 11.9 & SL & $\mathrm{Kt}>\mathrm{Qr}$ \\
\hline & Bw & $31-60$ & 22.2 & 19.7 & 24.1 & 34.0 & $\mathrm{LiC}$ & $\mathrm{Kt}, \mathrm{Qr}>\mathrm{Mc} / \mathrm{Vt}$ \\
\hline & Bt1 & $60-100$ & 4.4 & 21.0 & 22.4 & 52.2 & $\mathrm{HC}$ & $\mathrm{Kt}>\mathrm{Mc} / \mathrm{Vt}$ \\
\hline & Bt2 & $100-160$ & 0.3 & 23.9 & 19.4 & 56.4 & $\mathrm{HC}$ & $\mathrm{Kt}>\mathrm{Mc} / \mathrm{Vt}$ \\
\hline \multirow[t]{5}{*}{2} & Ap & $0-16$ & 42.3 & 43.6 & 11.9 & 2.2 & $\mathrm{LS}$ & $\mathrm{Qr}>\mathrm{Ht}$ \\
\hline & $\mathrm{AB}$ & $16-40$ & 53.9 & 21.9 & 20.6 & 3.6 & SL & $\mathrm{Qr}$ \\
\hline & Bt1 & $40-85$ & 43.0 & 29.2 & 23.0 & 4.8 & SL & $\mathrm{Qr}>\mathrm{Ht}$ \\
\hline & Bt2 & $85-110$ & 45.5 & 20.2 & 19.7 & 14.6 & SL & $\mathrm{Ht}>\mathrm{Qr}$ \\
\hline & $\mathrm{Bt} 3$ & $110-160$ & 35.4 & 17.0 & 16.1 & 31.5 & $\mathrm{LiC}$ & $\mathrm{Ht}>\mathrm{Qr}$ \\
\hline \multirow[t]{6}{*}{3} & $\mathrm{~A} 1$ & $0-5$ & 65.9 & 20.2 & 5.3 & 8.6 & LS & $\mathrm{Ht}>\mathrm{Qr}$ \\
\hline & A2 & $5-20$ & 66.1 & 17.8 & 5.0 & 11.1 & SL & $\mathrm{Ht}>\mathrm{Qr}$ \\
\hline & $\mathrm{AB}$ & $20-50$ & 42.8 & 11.2 & 4.6 & 41.4 & $\mathrm{LiC}$ & $\mathrm{Ht}$ \\
\hline & Bt1 & $50-100$ & 30.0 & 8.7 & 6.5 & 54.8 & $\mathrm{HC}$ & $\mathrm{Ht}$ \\
\hline & $\mathrm{Bt} 2$ & $100-120$ & 33.1 & 10.8 & 7.2 & 48.9 & $\mathrm{HC}$ & $\mathrm{Ht}$ \\
\hline & $\mathrm{BC}$ & $120-160$ & 23.6 & 17.8 & 9.7 & 48.9 & $\mathrm{HC}$ & $\mathrm{Ht}$ \\
\hline \multirow[t]{5}{*}{4} & $\mathrm{Ap}$ & $0-20$ & 74.7 & 17.1 & 5.0 & 3.2 & $S$ & $\mathrm{Ht}>\mathrm{Qr}$ \\
\hline & $\mathrm{AB}$ & $20-35$ & 64.8 & 10.6 & 5.8 & 18.8 & SCL & $\mathrm{Ht}>\mathrm{Qr}$ \\
\hline & BA & $35-60$ & 62.1 & 8.3 & 6.0 & 23.6 & SCL & $\mathrm{Ht}>\mathrm{Qr}$ \\
\hline & Bt1 & $60-105$ & 56.3 & 14.4 & 6.0 & 23.3 & SCL & $\mathrm{Ht}>\mathrm{Qr}$ \\
\hline & Bt2 & $105-160$ & 54.1 & 13.5 & 5.1 & 27.3 & SC & $\mathrm{Ht}>\mathrm{Qr}$ \\
\hline
\end{tabular}

* Quoted from Do et al. (2002).

** Abbreviations: HC, heavy clay; LiC, light clay; LS, loamy sand; S, sand; SC, sandy clay; SCL, sandy clay loam; SL, sandy loam.

*** Abbreviations: Ht, halloysite $(0.7 \mathrm{~nm})$; Kt, kaolinite; Mc, mica; Mc/Vt, mica/vermiculite mixed-layer mineral; Qr, quartz.

profiles 1 and 2, both paddy soils in northern Viet Nam, the $\mathrm{pH}$ was highest in the $\mathrm{AB}$ horizon with the values of 6.6 to 6.3 and rapidly decreased toward the surface and the bottom. This vertical variation of $\mathrm{pH}$ was not comparable with the variation of the total content of exchangeable cations. The $\mathrm{pH}$ of the $\mathrm{Ap}$ and $\mathrm{AB}$ horizons would increase under the development of the reduced condition during waterlogging. After harvest and ponding-water release the $\mathrm{pH}$ of the Ap horizon(s) probably decreased owing to the recovery of the oxidized condition. In profile 3 , the reforested area of central highlands, the $\mathrm{pH}$ did not much change with depth but was lowest in the $\mathrm{AB}$ horizon, different from profiles 1 and 2. The higher $\mathrm{pH}$ in the horizons below the $\mathrm{AB}$ horizon was considered to reflect accumulation of exchangeable cations in those horizons. In profile 4 , the cashew planted field in southern Viet Nam, the $\mathrm{pH}$ was lowest among the four profiles, showing the values nearly equal to or below 5.0 , and decreased gradually with depth.

\section{Total carbon}

Total $\mathrm{C}$ was regarded as coming from organic matter, because limestones would be 
Table 3. Selected chemical properties of grey degraded soils

\begin{tabular}{|c|c|c|c|c|c|c|c|c|c|c|c|}
\hline \multirow{2}{*}{$\begin{array}{l}\text { Profile } \\
\text { No } \\
\end{array}$} & \multirow{2}{*}{ Horizon } & \multirow{2}{*}{$\begin{array}{l}\mathrm{pH} \\
\left(\mathrm{H}_{2} \mathrm{O}\right) \\
\end{array}$} & \multirow{2}{*}{$\begin{array}{l}\text { Total C } \\
\left(\mathrm{g} \mathrm{kg}^{-1}\right)\end{array}$} & \multirow{2}{*}{$\begin{array}{l}\text { Total N } \\
\left(\mathrm{g} \mathrm{kg}^{-1}\right) \\
\end{array}$} & \multirow{2}{*}{$\begin{array}{l}\text { Available P } \\
\left(\mathrm{mg} \mathrm{kg}^{-1}\right)\end{array}$} & \multicolumn{5}{|c|}{ Exchangeable cations $\left(\mathrm{cmol}_{\mathrm{c}} \mathrm{kg}^{-1}\right)$} & \multirow{2}{*}{$\begin{array}{l}\text { Free Fe oxides } \\
\left(\mathrm{g} \mathrm{kg}^{-1}\right)\end{array}$} \\
\hline & & & & & & $\mathrm{Ca}$ & $\mathrm{Mg}$ & $\mathrm{K}$ & $\mathrm{Na}$ & Total & \\
\hline \multirow[t]{6}{*}{1} & Ap1 & 5.07 & 18.6 & 1.02 & 10.2 & 1.59 & 0.27 & 0.27 & 0.40 & 2.53 & 2.5 \\
\hline & Ap2 & 5.80 & 7.8 & 0.43 & 7.1 & 1.63 & 0.41 & 0.24 & 0.05 & 2.33 & 3.8 \\
\hline & $\mathrm{AB}$ & 6.61 & 1.9 & 0.19 & 0.8 & 1.36 & 0.37 & 0.23 & 0.03 & 1.99 & 5.0 \\
\hline & $\mathrm{Bw}$ & 5.15 & 3.2 & 0.30 & 1.3 & 1.84 & 0.88 & 0.25 & 0.08 & 3.05 & 11.9 \\
\hline & Bt1 & 5.07 & 2.8 & 0.36 & 0.7 & 1.16 & 0.71 & 0.30 & 0.08 & 2.25 & 13.7 \\
\hline & $\mathrm{Bt} 2$ & 4.91 & 1.8 & 0.37 & 4.5 & 0.59 & 0.73 & 0.31 & 0.10 & 1.73 & 13.0 \\
\hline \multirow[t]{5}{*}{2} & $\mathrm{Ap}$ & 5.70 & 17.8 & 0.63 & 36.7 & 1.17 & 0.25 & 0.21 & 0.07 & 1.70 & 1.3 \\
\hline & $\mathrm{AB}$ & 6.33 & 4.3 & 0.08 & 2.0 & 0.55 & 0.06 & 0.18 & 0.02 & 0.80 & 1.2 \\
\hline & Bt1 & 5.27 & 0.0 & 0.04 & 2.7 & 0.23 & 0.04 & 0.17 & 0.01 & 0.45 & 1.4 \\
\hline & $\mathrm{Bt} 2$ & 4.65 & 0.8 & - & 6.7 & 0.17 & 0.04 & 0.18 & 0.03 & 0.42 & 11.0 \\
\hline & Bt3 & 4.47 & 0.6 & 0.10 & 1.7 & 0.23 & 0.07 & 0.19 & 0.05 & 0.54 & 14.9 \\
\hline \multirow[t]{6}{*}{3} & $\mathrm{Al}$ & 5.65 & 7.3 & 0.21 & 6.6 & 0.53 & 0.53 & 0.23 & 0.01 & 1.30 & 1.6 \\
\hline & $\mathrm{A} 2$ & 5.32 & 4.8 & 0.17 & 2.7 & 0.45 & 0.59 & 0.23 & 0.03 & 1.30 & 3.0 \\
\hline & $\mathrm{AB}$ & 5.19 & 9.6 & 0.41 & 2.2 & 0.90 & 1.77 & 0.36 & 0.03 & 3.06 & 4.6 \\
\hline & Bt1 & 5.30 & 9.1 & 0.45 & 3.8 & 1.52 & 2.84 & 0.41 & 0.05 & 4.82 & 8.0 \\
\hline & $\mathrm{Bt} 2$ & 5.61 & 17.9 & 0.46 & 2.8 & 1.89 & 2.19 & 0.41 & 0.02 & 4.51 & 17.3 \\
\hline & $\mathrm{BC}$ & 5.73 & 5.4 & 0.18 & 1.2 & 2.08 & 1.93 & 0.53 & 0.05 & 4.59 & 14.0 \\
\hline \multirow[t]{5}{*}{4} & $\mathrm{Ap}$ & 5.12 & 5.5 & 0.19 & 9.9 & 0.21 & 0.06 & 0.19 & 0.03 & 0.49 & 0.5 \\
\hline & $\mathrm{AB}$ & 4.79 & 4.3 & 0.19 & 9.3 & 0.23 & 0.06 & 0.16 & 0.02 & 0.47 & 0.5 \\
\hline & $\mathrm{BA}$ & 4.71 & 3.5 & 0.19 & 3.7 & 0.27 & 0.06 & 0.18 & 0.02 & 0.53 & 1.4 \\
\hline & Bt1 & 4.72 & 3.3 & 0.18 & 7.9 & 0.25 & 0.07 & 0.15 & 0.03 & 0.50 & 0.4 \\
\hline & Bt2 & 4.53 & 2.4 & 0.17 & 2.0 & 0.23 & 0.07 & 0.19 & 0.03 & 0.52 & 0.6 \\
\hline
\end{tabular}

dissolved under $\mathrm{pH}$ 6.0. The total $\mathrm{C}$ content was generally low, ranging from $18.6 \mathrm{~g} \mathrm{~kg}^{-1}$ in the Ap1 horizon of profile 1 to $0.0 \mathrm{~g} \mathrm{~kg}^{-1}$ in the Bt1 horizon of profile 2 . The total $\mathrm{C}$ contents obtained in the present study were comparable with those reported for grey degraded soils in Viet Nam (Nguyen and Do, 1977; Nguyen and Tran, 1978; Dao, 1987; Thai and Nguyen, 1998). In profiles 1 and 2, the total $\mathrm{C}$ content was 18 to $19 \mathrm{~g} \mathrm{~kg}^{-1}$ in the Ap1 or Ap horizon. This is probably ascribed to the regular addition of organic amendments such as compost and crop residues. The total $\mathrm{C}$ content was less than $5 \mathrm{~g} \mathrm{~kg}^{-1}$ below the $\mathrm{AB}$ horizon; the horizons of Bt1 through Bt3 in profile 2 were essentially devoid of organic matter. In profile 3 , the total $\mathrm{C}$ content was lowest in the $\mathrm{A} 2$ horizon and highest in the Bt2 horizon. This distribution pattern of the total $\mathrm{C}$ content possibly indicates dissolution of organic components from the A2 horizon and accumulation of them at the $\mathrm{Bt} 2$ horizon and hence suggests occurrence of podzolization in profile 3 . In profile 4 , the total $\mathrm{C}$ content was lower than $6 \mathrm{~g} \mathrm{~kg}^{-1}$ throughout the profile and gradually decreased with depth; the distribution pattern of the total $\mathrm{C}$ content observed for profile 3 was not noticed for profile 4 .

\section{Total nitrogen}

The total $\mathrm{N}$ content was low for all the profiles, similar to the total $\mathrm{C}$ content, and suggested the generally poor $\mathrm{N}$ fertility of grey degraded soils. One of the reasons for the poor chemical fertility of grey degraded soils can be attributed to the insufficient level of organic matter. In profiles 1 and 2 , the total $\mathrm{N}$ content of the surface plowed horizon was 
1.0 and $0.6 \mathrm{~g} \mathrm{~kg}^{-1}$, respectively, but was relatively high, probably reflecting the regular addition of organic amendments and plowing-in of crop residues as agricultural practices; the total $\mathrm{N}$ content was equal to or below 0.4 and $0.1 \mathrm{~g} \mathrm{~kg}^{-1}$ in profiles 1 and 2, respectively, in the subsurface horizons. In profile 3 , the total $\mathrm{N}$ content tended to be lowest in the $\mathrm{A} 2$ horizon and highest in the $\mathrm{Bt} 2$ horizon, like the total $\mathrm{C}$ content. This supports the idea of the dissolution and accumulation of organic components within the profile. In profile 4 , the total $\mathrm{N}$ content was below $0.2 \mathrm{~g} \mathrm{~kg}^{-1}$ and hardly changed with depth.

\section{Available phosphorus}

The available $\mathrm{P}$ content expressed as $\mathrm{P}$ was $10 \mathrm{mg} \mathrm{kg}^{-1}$ for the Ap1 horizon of profile 1 and $37 \mathrm{mg} \mathrm{kg}^{-1}$ for the Ap horizon of profile 2. These relatively high available P contents are attributable to the application of $\mathrm{P}$ fertilizers to them. Even these values, however, were below the value of $44 \mathrm{mg} \mathrm{kg}^{-1}$ which is evaluated as a critical $\mathrm{P}$ content by the Truog method for the cultivated soils in Japan (Editorial Committee for Methods of Soil Environmental Analysis, 1997). The available P content in the subsurface horizons of profiles 1 and 2 and in all the horizons of profiles 3 and 4 was below $10 \mathrm{mg} \mathrm{kg}^{-1}$, and did not show a fixed pattern of variation within the profile.

\section{Exchangeable cations}

Generally speaking, the total content of exchangeable $\mathrm{Ca}, \mathrm{Mg}, \mathrm{K}$, and $\mathrm{Na}$, the effective CEC, was low, similar to the contents of total $\mathrm{C}$ and $\mathrm{N}$ and available $\mathrm{P}$. In profiles 1 and 2, it was lower for profile 2 than for profile 1 . Calcium was a main cation followed by $\mathrm{Mg}$ in profile 1 and by $\mathrm{K}$ in profile 2 . In profile 3 , the total content of exchangeable cations was noticeably higher for the Bt1 through BC horizons than for the upper three horizons, indicating leaching of exchangeable cations. In profile 4, the contents of individual cation hardly changed within the profile.

\section{Free iron oxides}

The content of free Fe oxides was generally low but was clearly higher for the lower horizons than for the upper ones, except for profile 4. In profile 1, the content of free Fe oxides expressed as $\mathrm{Fe}_{2} \mathrm{O}_{3}$ was 2.5 to $5.0 \mathrm{~g} \mathrm{~kg}^{-1}$ in the Ap1 through $\mathrm{AB}$ horizons while 11.9 to $13.7 \mathrm{~g} \mathrm{~kg}^{-1}$ in the Bw through Bt2 horizons. The corresponding values for profile 2 were 1.2 to 1.4 and 11.0 to $14.9 \mathrm{~g} \mathrm{~kg}^{-1}$. The difference in the content of free Fe oxides between the upper and lower horizons can be attributed to the vertical movement of them. In profile 3 , the content of free Fe oxides increased with depth and showed a maximum in the $\mathrm{Bt} 2$ horizon. In profile 4 , contrast to the other grey degraded soils, the content of free Fe oxides was quite low throughout the profile and showed no meaningful distribution.

\section{DISCUSSION}

\section{General chemical fertility}

Four grey degraded soils in Viet Nam were examined in the present study. They were different in land use, landform, and parent material, but the poor chemical fertility was generally understood. Profiles 1 and 2 are paddy soils in northern Viet Nam. The contents of total $\mathrm{C}$ and $\mathrm{N}$, available $\mathrm{P}$, and total exchangeable cations were relatively high in 
the surface Ap1 or Ap horizon as a result of agricultural practices. However, those values were evaluated to be too low to expect the optimum and sustainable crop growth. Generally speaking, organic matter and plant-available $\mathrm{N}, \mathrm{P}, \mathrm{K}, \mathrm{Ca}$, and $\mathrm{Mg}$ are all insufficient to the reasonable rice production. The low inherent potentiality of soil in the Ap horizon, controlled by the low clay content and by the inactive nature of composing minerals (Table 2), is partly responsible for the poor chemical fertility, because of its low retention or holding-capability. Soil dressing is mentioned as a possible soil management, but it is unlikely due to taking much cost and labor. Regular addition of considerable amounts of organic amendments is indispensable to improvement of the retention or holding-capability of the Ap horizon. Split dressing of appropriate amounts of chemical fertilizers is strongly recommended to suppress leaching of nutrients.

Profile 3 is the forest soil in central highlands. The chemical fertility was regarded as poor. However, it was not understood whether the soil supports normal growth of trees and wood production or not. Profile 4 is the soil planted with cashew in southern Viet Nam. This soil showed strong acidity in addition to the inferior chemical properties. It is expected that the growth and production of cashew is poor.

\section{Eluviation and illuviation of soil components}

Eluviation in the upper horizons and illuviation in the lower horizons were observed for organic components and free Fe oxides. The following two mechanisms were proposed as the eluviation and illuviation processes occurring in grey degraded soils, based on their distribution patterns within the profile.

\section{Reduction and oxidation}

The vertical distribution pattern of the free Fe oxides content observed for profiles 1 and 2 did not parallel the distribution pattern of the total $\mathrm{C}$ content. Because profiles 1 and 2 are paddy soils and have been subjected to the long-time cultivation of paddy rice, it is conceivable that the vertical movement of free $\mathrm{Fe}$ oxides is due to the reduction and oxidation process commonly occurring in paddy cultivation. Under waterlogging during the rice-growing season the reduced condition prevails in the Ap horizons. Ferric compounds are reduced to ferrous compounds. Ferrous compounds are more soluble and are transported with percolating water to the lower horizons where the oxidized condition is conserved. Ferrous compounds are reoxidized to ferric compounds and precipitated as Fe mottles there, leading to the distribution pattern of free Fe oxides of the lower content in the $\mathrm{Ap}$ and $\mathrm{AB}$ horizons and the higher content in the $\mathrm{Bt}$ horizons.

\section{Podzolization}

In profile 3 the vertical distribution pattern of the free $\mathrm{Fe}$ oxides content well paralleled the distribution pattern of the total $\mathrm{C}$ content, different from profiles 1 and 2 . Simultaneous movement of organic components and free Fe oxides is likely in profile 3. They are dissolved in the A1 and A2 horizons, transported, and precipitated and accumulated in the Bt2 horizon. The exact mechanism of dissolution and precipitation of organic components and free Fe oxides is not clear at present, but the mechanism similar to the formation of "Wet iron podzolic soils" is conceivable under the annual or seasonal wet condition controlled by the microrelief. "Wet iron podzolic soils" is the name by the 
Japanese forest soil classification and is formed by podzolization and surface-gleyzation under the cold and wet climatic condition (Kawada, 1989).

\section{"Degraded paddy field" and management}

The lower content of free $\mathrm{Fe}$ oxides in the $\mathrm{Ap}$ and $\mathrm{AB}$ horizons of profiles 1 and 2 suggests that they are so-called "degraded paddy field". The degradation is more progressing in profile 2, since the content of free $\mathrm{Fe}$ oxides in the $\mathrm{Ap}$ and $\mathrm{AB}$ horizons was lower for profile 2 than for profile 1 and the lower Fe content extended to the Bt1 horizon in profile 2. In "degraded paddy field" application of fertilizers including sulfate should be avoided. Otherwise, hydrogen sulfide will be formed after waterlogging; hydrogen sulfide changes to ferrous sulfide to be precipitated in the horizons containing sufficient amounts of free Fe oxides. Hydrogen sulfide is a strong respiration-inhibitor and adversely affects rice roots. As a result, growth of rice is suppressed in the latter half of the growing stage; this phenomenon is known as "akiochi" or autumn decline. Application of Fe-supplying material is strongly recommended to recover the Fe content of $A p$ and $A B$ horizons of "degraded paddy field".

\section{Clay degradation}

Although clay degradation in grey degraded soils was discussed in the previous paper (Do et al., 2002), it is again discussed briefly in the present study with availability of data on chemical properties. In profiles 1 and 2 subjected to the repetition of reduction and oxidation, decomposition of clay particles in addition to leaching and accumulation of them is considered as factors of the clay loss in the upper horizons. Ferrolysis, observed in grey terrace soils of Bangladesh by Brinkman $(1970,1977)$, is most probable as a mechanism of the decomposition of clay particles. In this mechanism, decomposition of clay particles is progressing through alternate reduction and reoxidation of ferrous iron. Decomposition of clay particles is more severe for profile 2 ; this is recognized from the lower clay content in the upper horizons and dominance of quartz over layer silicates in the clay fraction (Table 2). The leaching and accumulation process is that of deflocculation of clay particles in the upper horizons and flocculation of them in the lower horizons.

In profile 3 , leaching and accumulation is considered as a main mechanism of the clay loss. In this soil, organic components and free Fe oxides were also subjected to the dissolution and precipitation process. The Bt2 horizon was an accumulated layer of organic components and free Fe oxides, but it was the Bt1 horizon for clay particles. The lower clay content in the surface Ap horizon was observed for profile 4. The clay loss is less severe for profile 4 , and the chemical properties examined and the mineralogical composition in the clay fraction exhibited essentially no vertical variation. Therefore, the mechanism of the clay loss is still obscure, though erosion was considered as a principle process of the clay loss in the previous paper (Do et al., 2002).

\section{CONCLUSIONS}

The infertile chemical properties in the surface or upper horizons of grey degraded soils in Viet Nam are ascribed to the loss of chemical components caused by the eluviation and illuviation process and to the small retention or holding-capability as a result of the 
clay degradation. It makes the plant-nutrients management practice of grey degraded soils difficult. Regular addition of organic amendments and split dressing of chemical fertilizers are recommended in the crop cultivation. Chemical processes of reduction-oxidation (paddy soil) and podzolization (forest soil) were tentatively proposed as mechanisms of the formation of grey degraded soils in Viet Nam. They should be verified in the future study.

\section{ACKNOWLEDGEMENTS}

We express our sincere gratitude to Dr. Nguyen Huu Thanh, Department of Soil Science and Agrochemistry, Ha Noi Agricultural University, and Dr. Ho Quang Duc and Mr. Nguyen Van Ty, Department of Soil Genesis and Land Management, Viet Nam National Institute of Soils and Fertilizers for their assistance in collecting soil samples.

\section{REFERENCES}

Brinkman, R. 1970 Ferrolysis, a hydromorphic soil forming process. Geoderma, 3: 199-206

Brinkman, R. 1977 Surface-water gley soils in Bangladesh: genesis. Geoderma, 17: 111-144

Dao, C. T. 1987 Clay Minerals and Their Relation to Some Chemical Properties in Major Soils of Viet Nam. Ph. D. Thesis, Ha Noi Agricultural University, Ha Noi, Viet Nam (in Vietnamese)

Do, N. H., Q. H. Trinh and K. Egashira 2002 Mineralogy and clay degradation in grey degraded soils of Viet Nam. Clay Sci., 11: 535-547

Editorial Committee for Methods of Soil Environmental Analysis 1997 Methods of Soil Environmental Analysis. Hakuyusha, Tokyo (in Japanese)

Kawada, H. 1989 General Forest Soil Science. Hakuyusha, Tokyo (in Japanese), pp. 46-51

Nguyen, T. D., D. M. Le and T. L. Nguyen 1995 Effect of Organic Matter on Water and Physical Properties in Relation to Soil Fertility of Grey Degraded Soils in Hiep Hoa, Ha Bac Province. Scientific Research Project KN01-01. National Soil and Agrochemical Institute, Ha Noi, Viet Nam (in Vietnamese)

Nguyen, V. and D. T. Do 1977 Major Soil Types in Viet Nam. Technical and Scientific Public House, Ha Noi, Viet Nam

Nguyen, V. and K. Tran 1978 Soil Chemistry in North of Viet Nam. Technical and Scientific Public House, Ha Noi, Viet Nam (in Vietnamese)

Thai, P. and T. S. Nguyen 1998 Degraded Land and its Data Collection and Analysis in Viet Nam. National Institute of Soils and Fertilizers, Ha Noi, Viet Nam 